\title{
Doxycycline in serum and bronchial secretions
}

\author{
B. J. S. HART NETT and G. E. MARLIN \\ Respiratory Unit, Repatriation General Hospital, Concord, N.S.W., Australia
}

\begin{abstract}
Hartnett, B. J. S. and Marlin, G. E. (1976). Thorax, 31, 144-148. Doxycycline in serum and bronchial secretions. The concentration of doxycycline hydrochloride was measured in serum and bronchial secretions in five patients with chronic bronchitis receiving doxycycline orally in normal therapeutic dosage for seven days $(200 \mathrm{mg}$ day $1,100 \mathrm{mg}$ days 2 to 7). After the loading dose of $200 \mathrm{mg}$, serum concentrations ranged between 5.40 and $3.45 \mu \mathrm{g} / \mathrm{ml}$ (mean $4.33 \mu \mathrm{g} / \mathrm{ml}$ ) at 3 hours, declining to between 2.28 and $1.21 \mu \mathrm{g} / \mathrm{ml}$ (mean $1.71 \mu \mathrm{g} / \mathrm{ml}$ ) at 23 hours. The mean serum levels for days 2 to 7 were $2 \cdot 15,1 \cdot 79$, and $1 \cdot 38$ at 3,8 , and 23 hours respectively. There was considerable individual variability and a wide range of concentrations of doxycycline in the sputum $(0.07$ to $2.10 \mu \mathrm{g} / \mathrm{ml}$, mean $0.34 \mu \mathrm{g} / \mathrm{ml}$ ). During the course of treatment there was a progressive increase in sputum levels and sputum/serum concentration ratios. There was no correlation between sputum concentration and degree of purulence. The clinical efficacy of doxycycline does not appear to be related to sputum concentration, although the progressive increase in sputum doxycycline levels may be relevant in preventing recurrence of acute infection when the drug is administered as long-term prophylactic therapy.
\end{abstract}

Tetracyclines are commonly used as bacteriostatic chemotherapy for the treatment of acute exacerbations of chronic bronchitis. The most common infecting oganisms are Haemophilus influenzae and pneumococcus, which are both sensitive in vitro to tetracyclines (May, 1953 and 1964; May and May, 1963). The site of infection is the bronchial mucosa where an effective concentration of antibiotic must be reached to eliminate the organism (Hers and Mulder, 1953). A gradient of concentration of antibiotic presumably exists from blood through bronchial mucosa to bronchial secretions. The efficacy of treatment may also depend on the concentration of antibiotic in bronchial secretions. This concentration should be sufficient to suppress bacterial growth, otherwise there will remain a constant reservoir of organisms, and reinfection is likely, a major problem in the management of chronic bronchitis (May and Delves, 1965). An assessment of the response to chemotherapy may be provided if the concentration of antibiotic obtained in bronchial secretions is known.

Doxycycline (alpha-6-desoxytetracycline) hydrochloride is a tetracycline derivative which retains the antibiotic properties of this group but has other beneficial characteristics. The serum halflife in adult man is between 15 and 22 hours, so that a single daily dose is sufficient for therapy (Fabre et al., 1966; Rosenblatt et al., 1966; Jacobs and Robinson, 1969). There is only minimalo depression of absorption when doxycycline is administered with food (Rosenblatt et al., 1966), 을 and the drug may be used safely in patients with $\stackrel{x}{x}$ renal insufficiency (Little and Bailey, 1970).

The purpose of this work was $(a)$ to measure the concentration of doxycycline in bronchialo secretions in patients receiving doxycycline orally in normal therapeutic dosage over a seven-day옹 period, and $(b)$ to determine the relationship $>$ between serum and sputum concentrations of doxycycline.

\section{METHODS}

PATIENTS Five hospital patients with chronic bronchitis defined according to the terminologye of the Ciba Guest Symposium Report (1959) were selected for this study. All patients were able to $\stackrel{?}{+}$ produce ample quantities of sputum throughout ${ }_{T}$ the day and none had received treatment with $\frac{\vec{P}}{\bar{D}}$ antibiotics or mucolytic agents during the previous three days. Four patients had acute exacerbations $\stackrel{\mathbb{Q}}{\mathscr{Q}}$ of chronic bronchitis and were producing mucopurulent sputum at the time of entry to the study. 
There was no evidence of pneumonic consolidation on the chest radiograph of any patient. The informed consent of each patient was obtained after the procedure of the trial had been fully explained.

DESIGN Each patient received a seven-day course of doxycycline, starting with a loading dose of $200 \mathrm{mg}$ at 0900 hours on the first day and subsequently $100 \mathrm{mg}$ at the same time on the following six days. During the trial, supportive treatment with an aerosol bronchodilator (orciprenaline) and physiotherapy was continued at regular intervals. The patients received a light breakfast two hours before drug ingestion. Samples of venous blood and sputum were collected at intervals of 3,8 , and 23 hours after each dose of doxycycline. Sputum was accumulated in plastic containers during the 30-minute period before appointed collection times and was classified as mucoid, mucopurulent or purulent according to the quantity of pus present on naked-eye examination.

ASSAY OF DOXYCYCLINE The doxycycline concentration in serum and sputum samples was measured biologically by a large plate agar diffusion method, using a punch hole technique with Bacillus cereus (var. mycoides 11778) as test organism.

Serum Assay Standard solutions of doxycycline $(0 \cdot 1,0 \cdot 2,0 \cdot 4,0 \cdot 6,1 \cdot 0$, and $2 \cdot 0 \mu \mathrm{g} / \mathrm{ml})$ were prepared using 1:2 Bovine Albumin 3.5\% solution and phosphate buffer $\mathrm{pH} 4.5$ as diluent.

Sputum Assay Sputum from six other bronchitic patients not receiving treatment with antibiotics was homogenized by centrifugation at $10000 \mathrm{rev/}$ $\min$ for 30 minutes for the preparation of $0 \cdot 1$, $0.2,0.4,0.8,2.0$, and $3.0 \mu \mathrm{g} / \mathrm{ml}$ doxycycline standards. In preliminary studies there was no significant difference in results obtained by preparing the sputum by conventional centrifugation, ultracentrifugation or proteolytic homogenization.

Preparation of Assay Plates A fresh overnight culture of $B$. cereus was prepared and washed from an agar slope with sterile distilled water to give a suspension having a $50 \%$ transmission at $650 \mathrm{~m} \mu$ on a visible spectrophotometer. The suspension was shaken for one hour to produce homogeneity and used as a $1 \%$ inoculum. Assay plates were prepared with a layer of $250 \mathrm{ml}$ seed agar BBL 10937, with $\mathrm{pH} 7.0$ containing $2.5 \mathrm{ml}$ of the prepared suspension of $B$. cereus. The assay method then followed the procedure described by Campbell (1970). The lower limit of detectability of doxycycline by this method in both serum and sputum was $0.01 \mu \mathrm{g} / \mathrm{ml}$, and the variability of estimations was less than $5 \%$.

\section{RESULTS}

The mean serum and sputum doxycycline concentrations for the five patients at 3,8 , and 23 hours after each dose of the drug are shown in Tables I and II respectively. Statistical analysis of these results was performed using the paired Student's $t$ test.

Peak serum doxycycline concentrations were recorded 3 hours after dosage on each day of the trial, and although there was a subsequent decline, appreciable concentrations were detected 23 hours after ingestion. After the loading dose of $200 \mathrm{mg}$,

T A B L E I

MEAN \pm STANDARD ERROR OF THE MEAN SERUM DOXYCYCLINE CONCENTRATIONS FOR THE FIVE PATIENTS AT 3, 8, AND 23 HOURS AFTER $200 \mathrm{mg}$ ON DAY 1 AND $100 \mathrm{mg}$ ON DAYS 2 TO 7 OF TREATMENT

\begin{tabular}{|c|c|c|c|c|c|c|c|}
\hline \multirow[b]{2}{*}{ Hours } & \multicolumn{7}{|c|}{ Serum Concentrations (Mean \pm SEM) $(\mu \mathrm{g} / \mathrm{ml})$} \\
\hline & Day 1 & Day 2 & Day 3 & Day 4 & Day 5 & Day 6 & Day 7 \\
\hline $\begin{array}{r}3 \\
8 \\
23\end{array}$ & $\begin{array}{l}4.33 \pm 0.35 \\
2.92 \pm 0.35 \\
1.71 \pm 0.19\end{array}$ & $\begin{array}{l}2 \cdot 73 \pm 0.33 \\
2 \cdot 19 \pm 0.43 \\
2.05 \pm 0.61\end{array}$ & $\begin{array}{l}2.03 \pm 0.49 \\
1.93 \pm 0.32 \\
1.67 \pm 0.46\end{array}$ & $\begin{array}{l}1.86 \pm 0.22 \\
1.58 \pm 0.25 \\
1.09 \pm 0.22\end{array}$ & $\begin{array}{l}2.13 \pm 0.31 \\
1.76 \pm 0.23 \\
1.15 \pm 0.20\end{array}$ & $\begin{array}{l}2 \cdot 20 \pm 0 \cdot 18 \\
1 \cdot 53 \pm 0 \cdot 18 \\
1 \cdot 29 \pm 0 \cdot 30\end{array}$ & $\begin{array}{l}1.98 \pm 0.20 \\
1.71 \pm 0.19 \\
0.93 \pm 0.13\end{array}$ \\
\hline
\end{tabular}

T A B L E I I

MEAN \pm STANDARD ERROR OF THE MEAN SPUTUM DOXYCYCLINE CONCENTRATIONS FOR THE FIVE PATIENTS AT 3, 8, AND 23 HOURS AFTER $200 \mathrm{mg}$ ON DAY 1 AND $100 \mathrm{mg}$ ON DAYS 2 TO 7 OF TREATMENT

\begin{tabular}{|c|c|c|c|c|c|c|c|}
\hline \multirow[b]{2}{*}{ Hours } & \multicolumn{7}{|c|}{ Sputum Concentrations (Mean $\pm \operatorname{SEM})(\mu \mathrm{g} / \mathrm{ml})$} \\
\hline & Day 1 & Day 2 & Day 3 & Day 4 & Day 5 & Day 6 & Day 7 \\
\hline $\begin{array}{r}3 \\
8 \\
23\end{array}$ & $\begin{array}{l}0.23 \pm 0.12 \\
0.19 \pm 0.02 \\
0.13 \pm 0.02\end{array}$ & $\begin{array}{l}0.31 \pm 0.04 \\
0.23 \pm 0.05 \\
0.22 \pm 0.11\end{array}$ & $\begin{array}{l}0.30 \pm 0.06 \\
0.25 \pm 0.02 \\
0.21 \pm 0.06\end{array}$ & $\begin{array}{l}0.29 \pm 0.06 \\
0.42 \pm 0.06 \\
0.23 \pm 0.03\end{array}$ & $\begin{array}{l}0.41 \pm 0.16 \\
0.47 \pm 0.16 \\
0.35 \pm 0.12\end{array}$ & $\begin{array}{l}0.62 \pm 0.37 \\
0.45 \pm 0.17 \\
0.36 \pm 0.19\end{array}$ & $\begin{array}{l}0.57 \pm 0.21 \\
0.51 \pm 0.18 \\
0.41 \pm 0.17\end{array}$ \\
\hline
\end{tabular}


serum concentrations ranged between 5.40 and $3.45 \mu \mathrm{g} / \mathrm{ml}$ (mean $4.33 \mu \mathrm{g} / \mathrm{ml}$ ) at 3 hours, declining to between 2.28 and $1.21 \mu \mathrm{g} / \mathrm{ml}$ (mean 1.71 $\mu \mathrm{g} / \mathrm{ml}$ ) at 23 hours. The mean serum levels for days 2 to 7 were $2 \cdot 15,1 \cdot 79$, and $1.38 \mu \mathrm{g} / \mathrm{ml}$ at 3,8 , and 23 hours respectively. The peak serum levels on days 1 and 2 were significantly higher than on day $7(\mathrm{P}<0.01)$, confirming a loading dose effect and suggesting that plateau levels were achieved after two days of treatment.

Doxycycline was detectable in the sputum throughout the study, including the first specimens 3 hours after starting treatment. Sputum concentrations were lower than those achieved at corresponding times in the serum, ranging from $2.3 \%$ to $77.5 \%$ (mean $19.9 \%$ ) of the serum value. Peak levels were observed usually 3 hours after dosage, and in most instances declined at 23 hours. There appeared to be a gradual accumulation of doxycycline in the sputum as the treatment proconcentrations on days 1,2 , and 3 were significantly less than on days 3 to 7 , day 7 , and days 4 and 7 respectively $(\mathrm{P}<0.05)$. The sputum/serum concentration ratio also increased progressively throughout the trial (see Table III and Figure).

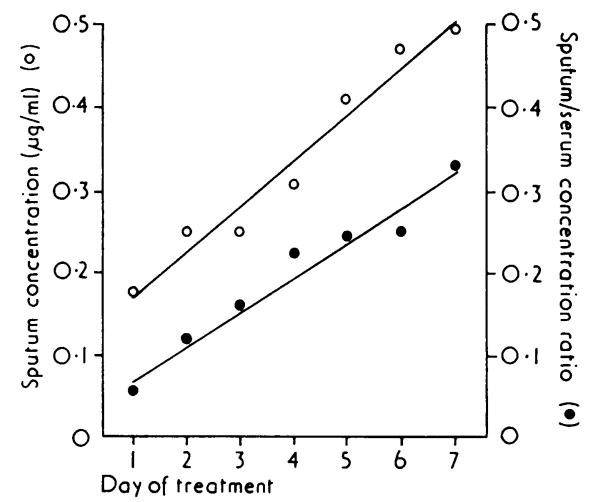

FIGURE Mean sputum concentrations and sputum/ serum concentration ratios of doxycycline for the five patients for the one-day period after each dosage (200 $\mathrm{mg}$ on day $1,100 \mathrm{mg}$ on days 2 to 7) plotted against day of treatment. gressed (see Table II and Figure). The sputum

These ratios on days 1,2 , and 3 were significantly less than on days 2 to $7(\mathrm{P}<0.01)$, days 4 to $7 z$ $(\mathrm{P}<0.05)$, and days 4 and $7(\mathrm{P}<0.05)$ respectively. Pus was eliminated from the bronchial secretions within 48 hours in all four patients who had mucopurulent sputum at the start of the trial.

\section{DISCUSSION}

There was considerable individual variability and a wide range of concentrations of doxycycline in bronchial secretions, a finding observed with other antibiotics in chronic bronchitis (Hafez, Stewart, and Burnet, 1965; May and Delves, 1964 and 1965; Campbell, 1970; Stewart et al., 1970; May and Ingold, 1972; MacCulloch, Richardson, and Allwood, 1974; Stewart et al., 1974). Careful precautions were taken to avoid dilution of sputum by salivary contamination, although this is unlikely to alter sputum levels appreciably (May and Delves, 1965). The range of sputum concentrations of doxycycline was generally low $(0.07$ to $2.10 \mu \mathrm{g} / \mathrm{ml}$, mean $0.34 \mu \mathrm{g} / \mathrm{ml}$ ) and similar to that observed by MacCulloch et al (1974) after a comparable dosage regimen $(0.05$ to $3.40 \mu \mathrm{g} / \mathrm{ml}$, mean $0.86 \mu \mathrm{g} / \mathrm{ml}$ ). This poor excretion into the sputum is particularly noticeable during the first 48 hours despite the administration of a loading dose. Campbell (1970) also observed that sputum tetracycline levels were lower during the first 24 hours of therapy and often only peaked after 48 hours. Administration of a higher daily dose of doxycycline might result in higher sputum concentrations.

The progressive increase in sputum doxycycline concentration during the course of treatment occurred despite lack of accumulation in the 8 serum. This behaviour has not previously been observed with other antibiotics and might be re- 윽 lated to the drug's long half-life. However, penetration of doxycycline into bronchial secretions does not appear to be a simple diffusion process, because of lack of correlation between $\odot$ serum and sputum levels. An active transport 0 mechanism for excretion into sputum would $\underset{\mathrm{C}}{\mathrm{W}}$ favour accumulation of the drug in this reservoir.

T A B L E I I I

MEAN \pm STANDARD ERROR OF THE MEAN SPUTUM/SERUM DOXYCYCLINE CONCENTRATION RATIOS FOR THE FIVE C PATIENTS AT 3, 8, AND 23 HOURS AFTER $200 \mathrm{mg}$ ON DAY 1 , AND $100 \mathrm{mg}$ ON DAYS 2 TO 7 OF TREATMENT

\begin{tabular}{|c|c|c|c|c|c|c|c|}
\hline \multirow[b]{2}{*}{ Hours } & \multicolumn{7}{|c|}{ Sputum/Serum Concentration Ratio (Mean \pm SEM) } \\
\hline & Day 1 & Day 2 & Day 3 & Day 4 & Day 5 & Day 6 & Day 7 \\
\hline $\begin{array}{r}3 \\
8 \\
23\end{array}$ & $\begin{array}{l}0.053 \pm 0.003 \\
0.066 \pm 0.010 \\
0.075 \pm 0.003\end{array}$ & $\begin{array}{l}0.121 \pm 0.018 \\
0.126 \pm 0.042 \\
0.132 \pm 0.050\end{array}$ & $\begin{array}{l}0.167 \pm 0.036 \\
0.147 \pm 0.069 \\
0.171 \pm 0.062\end{array}$ & $\begin{array}{l}0.160 \pm 0.019 \\
0.282 \pm 0.046 \\
0.231 \pm 0.028\end{array}$ & $\begin{array}{l}0.178 \pm 0.048 \\
0.267 \pm 0.089 \\
0.284 \pm 0.074\end{array}$ & $\begin{array}{l}0.248 \pm 0.128 \\
0.286 \pm 0.097 \\
0.237 \pm 0.056\end{array}$ & $\begin{array}{l}0.265 \pm 0.078 \\
0.283 \pm 0.460 \\
0.460 \pm 0.154\end{array}$ \\
\hline
\end{tabular}


This would also be evident if the drug was bound to constituents of the sputum, eg, protein. It is known that doxycycline is highly bound to serum proteins (Rosenblatt et al., 1966). Doxycycline has high lipid solubility necessary for penetrating cell membranes readily and may also bind strongly to bronchial epithelial cell constituents. If the drug is released only slowly from these cells, its initial availability for penetrating into the sputum will be reduced.

There was no correlation between sputum concentrations and degree of purulence, in contrast to the behaviour of ampicillin whose transport is facilitated by the presence of pus (May and Delves, 1965; Stewart et al., 1970). Nevertheless, tissue levels of doxycycline during the first 48 hours were apparently adequate as pus was eliminated from the sputum in the four patients presenting with mucopurulent secretions. Liss and Norman (1975) found doxycycline levels of between 2.87 and $4.95 \mu \mathrm{g} / \mathrm{g}$ tissue in the lungs of patients undergoing cardiopulmonary surgery after $200 \mathrm{mg} 24$ hours, and after $100 \mathrm{mg} \mathrm{5-7}$ hours, before surgery. They observed by fluorescent microscopy the highest concentration of doxycycline in the bronchiolar epithelium. Gartmann (1975) determined doxycycline concentrations in human surgical lung specimens after 200 $\mathrm{mg}, 27$ hours and $100 \mathrm{mg}$ approximately 3 hours before surgery and found levels of between 1.0 and $8.5 \mu \mathrm{g} / \mathrm{g}$ in lung tissue, between 1.89 and $3.49 \mu \mathrm{g} / \mathrm{g}$ in bronchial wall, and usually below $1.0 \mu \mathrm{g} / \mathrm{ml}$ in bronchial secretions. The mean inhibitory concentration (MIC) of doxycycline against Haemophilus influenzae is $1.0 \mu \mathrm{g} / \mathrm{ml}$ and against the pneumococcus $0 \cdot 19 \mu \mathrm{g} / \mathrm{ml}$ (Williamson, 1968), such levels being reached in lung and bronchial wall but not consistently in bronchial secretions for $H$. influenzae. In this present study, only in two patients during the latter half of treatment were sputum levels greater than the MIC for $H$. influenzae, but they reached that for the pneumococcus in all patients at least on one collection time each day.

Doxycycline has proved to be an effective antibiotic in the treatment of acute exacerbations of chronic bronchitis with efficacy similar to ampicillin (Aitchison, Grant, and Gould, 1968; Bennion-Pedley, 1969) and oxytetracycline (British Thoracic and Tuberculosis Association, 1973). The results of this study indicate that the clinical efficacy of doxycycline does not appear to be directly related to sputum concentration but more likely to levels achieved in lung and bronchial wall. The progressive increase in sputum concentration observed during treatment may be of relevance to the suppression of bacterial growth and the recurrence of acute infection when doxycycline is administered as long-term prophylactic therapy.

We wish to thank Dr. B. W. Gunner, Medical Director, Pfizer Pty Ltd, for providing helpful advice and supplies of doxycycline. We are also indebted to Mr. R. Keating, B. Pharm., Pfizer Pty Ltd, who performed the doxycycline assays, and to Dr. G. Graham for statistical advice.

\section{REFERENCES}

Aitchison, W. R. C., Grant, I. W. B., and Gould, J. C. (1968). Treatment of acute exacerbations in chronic bronchitis. British Journal of Clinical Practice, 22, 343.

Bennion-Pedley, J. (1969). Treatment of acute exacerbations of chronic bronchitis in general practice. British Journal of Clinical Practice, 23, 280.

British Thoracic and Tuberculosis Association (1973). Doxycycline and oxytetracycline in bronchitisa double blind controlled trial. British Journal of Diseases of the Chest, 67, 114.

Campbell, M. J. (1970). Tetracycline levels in bronchial secretions. Journal of Clinical Pathology, 23, 427.

Ciba Guest Symposium Report (1959). Terminology, definitions, and classification of chronic pulmonary emphysema and related conditions. Thorax, 14, 286.

Fabre, J., Pitton, J. S., and Kunz, J. P. (1966). Distribution and excretion of doxycycline in man. Chemotherapy, 11, 73.

Gartmann, J. (1975). Doxycycline concentrations in lung tissue, bronchial wall, and bronchial secretions. Chemotherapy, 21, Supplement 1, 19.

Hafez, F. F., Stewart, S. M., and Burnet, M. E. (1965). Penicillin levels in sputum. Thorax, 20, 219.

Hers, J. F. P. and Mulder, J. (1953). The mucosal epithelium of the respiratory tract in mucopurulent bronchitis caused by Haemophilus influenzae. Journal of Pathology and Bacteriology, 66, 103.

Jacobs, P. and Robinson, R. (1969). Experiences with doxycycline in the management of acute respiratory tract infections. South African Medical Journal, 43, 206.

Liss, R. H. and Norman, J. C. (1975). Visualisation of doxycycline in lung tissue and sinus secretions by fluorescent techniques. Chemotherapy, 21, Supplement 1, 27.

Little, P. J. and Bailey, R. R. (1970). Tetracyclines and renal failure. New Zealand Medical Journal, $72,183$.

MacCulloch, D., Richardson, R. A., and Allwood, G. K. (1974). The penetration of doxycycline, oxytetracycline and minocycline into sputum. New Zealand Medical Journal, 80, 300. 
May, J. R. (1953). The bacteriology of chronic bronchitis. Lancet, 2, 534.

(1964). Ampicillin in the therapy of chronic bronchitis. Postgraduate Medical Journal, 40, Supplement, 193.

and Delves, D. M. (1964). Ampicillin in the treatment of Haemophilus influenzae infections of the respiratory tract. Thorax, 19, 298.

_ and - (1965). Treatment of chronic bronchitis with ampicillin: some pharmacological observations. Lancet, 1, 929.

- and Ingold, A. (1972). Amoxycillin in the treatment of chronic non-tuberculous bronchial infections. British Journal of Diseases of the Chest, 66, 185 .

and May, D. S. (1963). Bacteriology of sputum in chronic bronchitis. Tubercle, 44, 162.
Rosenblatt, J. E., Barrett, J. E., Brodie, J. L., and Kirby, W. M. M. (1966). Comparison of in vitro activity and clinical pharmacology of doxycycline with other tetracyclines. Antimicrobial A gents and Chemotherapy, 134.

Stewart, S. M., Anderson, I. M. E., Jones, G. R., and Calder, M. A. (1974). Amoxycillin levels in sputum, serum and saliva. Thorax, 29, 110.

Fisher, M., Young, J. E., and Lutz, W. (1970). Ampicillin levels in sputum, serum and saliva. Thorax, 25, 304.

Williamson, G. M. (1968). The in vitro activity of Vibramycin (doxycycline). Chemotherapy, 13, Supplement 1.

Requests for reprints to: Dr. G. E. Marlin, Repatriation General Hospital, Concord, N.S.W. 2139, Australia. 